\title{
Evaluation of the Demographic Situation in Sudan During 2000 and 2004 Using GIS Techniques
}

\author{
Adil M. A. Elsinnari ${ }^{1}$, Fathi M. M. Saeed ${ }^{2}$ \\ Hanadi Hassan Mahgoub Badi ${ }^{3}$
}

\begin{abstract}
The study focused on applying GIS technology to investigate the demographic situation in Sudan during year 2000 and 2004. This includes investigations of the basic environmental indicators and their impacts on population distribution in Sudan at that period. Sudan political map and other thematic maps of the country (produced in 2000 by the UN) together with the population sheets issued for Sudan by UN in 2000, 2001, 2002 and 2004 were used to generate a GIS model for the study area. Based on this model the main demographic indicators were spatially and statistically analyzed. A projected decline in demographic status was remarked. During 2000 and 2004 Sudan was suffering from a general to severe degradation in population activity. This was found to be true in all demographic indicators evaluated in this study. Severe degradation rates were remarked for indicators associated with sex and age. For example a great degradation in sex ratio was taken place in most of the states of the country (in the range of $6.12 \%$. to $73.19 \%$ ). This degradation reflects a critical situation, where the structure of these indicators can have considerable impacts on the population's social and economic situation, both present in the future. The study also concluded that the population distribution was found to be affected by the average annual rainfall, agricultural activities and geological structures.
\end{abstract}

Key words: Population, GIS, Demography, Literacy, Growth.

\footnotetext{
${ }^{1}$ Assistant Prof. . -Faculty of Eng. Sciences-Omdurman Islamic University

${ }^{2}$ Associate Prof. -Faculty of Eng. Sciences-Omdurman Islamic University

${ }^{3}$ National Population Council
} 


\section{Introduction}

Modeling, monitoring and analyzing population indicators is a difficult task. This is especially true for developing countries like Sudan, where the poor economic circumstances pose severe problems for monitoring and managing the demographic situation. The country is suffering from lack of a well-established and integrated population systems. However, as population continue to grow and the need for further socio-economic development increases, more and more pressure is being put on both renewable and non-renewable natural resources. Natural factors, in addition to irrational human activities, have led to many environmental problems including, among others, deforestation, soil erosion, over grazing, desertification, loss of biodiversity, pollution, malnutrition and infant mortality. This, no doubt, has adversely affected the continued efforts and noble objectives targeted towards population development and poverty alleviation. It is very clear that traditional means are not sufficient enough to play a role in updating, mapping, monitoring and managing the demographic indicators in Sudan. New digital approaches based on new techniques should be adopted to map the whole country and to establish powerful population systems.

The recent explosion in data gathering, linkage and analysis capabilities fostered by computing technology, particularly the Geographic Information System (GIS) which has greatly improved the ability to measure and assess these patterns. Geographic Information Systems are powerful automated systems for the capture, storage, retrieval, analysis, and display of spatial data. GIS offers new and expanding opportunities for epidemiology because it allows an informed user to choose between options when geographic distributions are part of the problem [1]. Much of that power stems from the system's spatial analysis capabilities, which allow users to examine and display population data in new and highly effective ways. Spatial analysis refers to the ability to manipulate spatial data into different forms and extract additional meaning as a result. It encompasses the many methods and procedures, developed in geography, statistics, and other disciplines, for analyzing and relating spatial information. On the other hand, large and complex geo-referenced data sets are now readily available through spatial data clearinghouses. This facilitating analyses by researchers unaffiliated with the government agencies that have historically controlled data access. Meanwhile, increasingly sophisticated statistical 
tools have evolved to keep pace with the increased data availability and computing power. GIS is particularly well suited for studying these associations because of its spatial analysis and display capabilities.

\section{Population and Demographic Indicators}

Population is the collection of people or organisms of a particular species living in a given geographic area or space, usually measured by a census. The structure of a population describes the relative numbers of people with similar characteristics within a population. It shows how the subgroups within it affect its composition and characteristics. Distribution of a population within a defined area can be an important factor to consider in planning and analysis work. Population structure changes over time as people age, but also because of births, deaths and migration. Changes to social, environmental and economic conditions can also influence population structure. The interrelationship between population, society, economics and the environment defines a population's future size and make-up [2].

Population can be measured in three ways: actual counts of people, estimates of changes in actual counts due to population growth from births, deaths and migration, and projections of changes to future numbers of inhabitants. Population issues are events and processes occurring within the population which have substantial demographic, social, economic or environmental implications [3].

Demography is the statistical study of human populations. It is a general science that can be applied to any kind of dynamic population, that is, one that changes over time or space. It encompasses the study of the size, structure and distribution of populations, and spatial and/or temporal changes in them in response to birth, death, migration and aging. Demographic analysis can be applied to whole societies or to groups defined by criteria such as education, nationality, religion and ethnicity [4].

Demographic data is a valuable source of information on population characteristics for informing policy and planning. But choosing the appropriate population information to apply to policy and planning is a complex process. Collection of demographic data is a constituent part of monitoring the demographic situation in a country. The quality of primary data defines the quality of derived demographic indicators. Comparability of different demographic indicators across countries depends not only upon the 
quality of the primary data but also upon the definitions used to derive demographic indicators [5].

Age and sex are the most basic characteristic of a population that can have considerable impact on the population's social and economic situation. The sex ratio is defined as the number of males to every 100 females. It is a basic demographic statistic. Other indicators include population growth rate, literacy rate, labor force participation rate, Crude Birth Rate (CBR), Crude Death Rate (CDR), Infant Mortality Rate (IMR), life expectancy at birth and Total Fertility Rate (TFR). Literacy rate is the percentage of population aged 10-24 years who can both read and write. CBR is defined as the number of live births per 1000 persons occurring during the year, while CDR is the number of deaths during the year per 1,000 persons. IMR is the number of infants who die in a given year before reaching one year of age per 1,000 live births, while the TFR is the total number of children an average woman will bear in her lifetime in the absence of mortality [6].

\section{Methodology}

The analogue political map of Sudan was digitized and delineated into a digital vector map that can be handled by a GIS system within a computer environment. The topology of the vector map as well as thematic maps of Sudan concerning underground water, rainfall, agriculture, soil types and geological structures (available as shape-files) was constructed to build a GIS geo-database. Internal members of this geo-database were generated by creating a dataset that describes the geographical location of the study area. Clarke 1880 geographic coordinate system was selected as a projection system for the generated dataset. Thus all layers derived from the raw data have been converted into feature-classes as internal members of the main geo-database. The attributes of these feature-classes were created based on the database associated with each shape-file layer.

In order to bring the Sudan political vector map into a common georeference with the created dataset of the study area, nine points at the crosssections of the vector map grid coordinates were used as control points to project the coordinates of the map into Clarke 1880 projection system. As a result a new feature-class defines the geographic location of the Sudan states was created. The attributes of this feature-class were obtained from the demographic indicators sheet for years 2000, 2001, 2002, and 2004.

A GIS model for the study area was developed. The model was generated by adding the population feature-class together with the Sudan 
states feature-class. The population growth for successive years during 2000 and 2004 has been extracted based on database query process. The growth was extracted for each state. The basic demographic indicators were modeled by generating geographic layers showing the variations in these indicators over Sudan' states. Each layer was combined with a graphical chart indicating these variations. The charts were produced based on statistical analysis applied to relational databases.

The environmental impacts on the population distribution in Sudan were modeled by overlaying the basic environmental feature-classes (underground water, rainfall, agricultural activities, soil types and geological structures) with the population feature-class. Thus a new feature-class was produced. This class defines the implicit relationship between population distribution and the individual environmental indicators. The relations were revealed by subjecting the generated class to a query process. The process was carried out to highlight the poor and density populated areas at state level within specific environmental indicator class. The population growth was spatially analyzed against underground water distribution and availability, rainfall, agricultural cover, soil types, and geological structures. This was done by extracting the areas with the highest and lowest growth rates. The behavior of each environmental indicator was investigated in terms of the similarity in both areas. This was applied to the other demographic indicators.

Based on the results of the spatial overlaying process statistical analysis have been carried out to evaluated and assessed the demographic situation in each state. The assessment was reached by studying and investigating both population indicator activities and environmental impacts extracted from the developed GIS model of the study area.

\section{Results and Analysis}

Digital thematic maps of Sudan, showing the political states (with population data), underground water, rainfall, agriculture, soil and geological province have been generate and coded in a GIS model. Population growths at state level during 2000 and 2004 are shown in Figure 1 and summarized in Table 1. Since estimated population size for some of the southern states was not available, the growth rate in these states was not computed. The average growth rate was found to be $9.55 \%$ which is equivalent to 180632 persons. Gezera state maintained the highest growth rate (18.81\%) during 2000 and 2004. The lowest rate was remarked in Red Sea state. Although Khartoum 
state achieved the highest population size in years 2000 and 2004 the growth rate was $17.15 \%$ (the second highest rate). The growth rate in western Darfur and western Bahr Elghazal states was approximately equal to the average growth rate. In general the growth rate in the northern and central regions of the country was in the range of $6.01 \%$ to $9.00 \%$ (less than the average growth rate). The growth in western region was in the range of $12.01 \%$ to $15.000 \%$. For the eastern region of the country, the growth rate was found to be varied.

Figure 2 shows the results of the modeling process applied to some of the demographic indicators at state level during 2000 and 2004. The corresponding attributes of these layers are given in Table 2. Figure 3 shows graphical analysis of these indicators. A gentle degradation in the annual growths was remarked in all Sudan states except Kassala and South Kordofan states where the situation remained as it is. Khartoum and West Kordofan maintained the highest degradation rate $(14.45 \%)$. The lowest degradation rate $(0.39 \%)$ was recorded for West Darfur state.

The demographic indicators "under age five" and "under age 15" witnessed gentle degradation during 2000 and 2004. The highest degradation rate for these indicators was recorded for West Equatoria (13.89\%) and Blue Nile $(9.79 \%)$ states, respectively. The lowest rates were $1.26 \%$ and $1.3 \%$ for Kassala and Khartoum states, respectively. The image was approximately the same for the ages between 6 and 24 years. Most of the country states recorded degradation rates between $1.88 \%$ (White Nile state) and $25.43 \%$ (West Darfur state). Regarding to the negative impacts of the demographic indicators, a growth rates between $28 \%$ (River Nile state) and $0.25 \%$ (Northern state) was remarked for age 60 and over. While for women between age 15 and 45 the highest degradation rate $(20.45 \%)$ was remarked in Khartoum state. A lowest rate of $0.97 \%$ was recorded for the Blue Nile state. This indicates a projected decline in population. The reasons behind this situation may be due to continuous external migration that might be taken place in the country during 2000 and 2004. However, such degradation may be a strong indication of the low level of the Crude Birth Rate (CBR). A great degradation in sex ratio was taken place in most of the states of the Sudan during. A degradation rate of $73.19 \%$ was recorded for Gezera state. The rate in Khartoum state was $6.12 \%$.

While degradation in the Literacy Rate (LR) was detected in the far western region of the country, gentle growths were detected in the northern and central regions. No information was available for most of the southern states. The River Nile and Northern states maintained the highest growth rates 
(3.69\% and $3.23 \%$, respectively). The growth rate in Khartoum state was $0.67 \%$. The highest degradation rate was detected in West Bahr Elgazal state (23.87\%). The lowest degradation rate was $1.23 \%$ (White Nile state). It is quite clear that high percentage of the population in the country is illiterate.

The highest growth for the Total Fertility Rate (TFR) was $9.93 \%$ (Kassala state), while the lowest rate was $2.13 \%$ (Khartoum state). On the other hand the highest degradation rate was $39.01 \%$ (West Bahr Elgazal state), while the lowest degradation rate was $2.13 \%$ (White Nile, Sinnar and River Nile states). No changes were detected for Gezera, West Darfur, West Kordofan and Northern states.

Table 3 reflects the behavior of the environmental indictors in areas with the highest and lowest population growth rates. The distribution of underground water seams to have no impacts on population growth rate in the study area. This is likely true where the same water class (class 1) has maintained the highest percentage (approximately 99\%) in both areas. For the rainfall the image was different. While the rainfall rate in most of the areas with lower growth rate was less than four inches, the rainfall rate in areas with highest growth rate was between 20 and 40 inches. This indicates that lack of rain may be one of the reasons that affecting population distribution in the study area. The same image is true for the geological structures. A great difference was remarked for the geological structures in density populated areas and poor areas. Geological structures were found to be completely different in these areas. Agricultural activities in areas with high growth rate were different from those in low growth rate areas. Traditional agriculture was the main agricultural activity in density populated areas $(81.73 \%)$, while in poor areas only scattered vegetation was available $(100 \%)$. This is a good indication that agricultural activities have great impacts on population distribution in Sudan. Although different soil types were found here and there, basement soil type was found to be extended over large cover in both areas (50.95\% and $89.92 \%$, respectively). This again indicates that soil type variations have no remarkable impacts on the population distribution in the study area.

\section{Conclusion}

Demographic situation in Sudan during 2000 and 2004 was suffering from a general to severe degradation. Due to the continuous external migration that might be taken place in the country during that period a 
projected decline in population was remarked. A gentle degradation in the annual growths during year 2000 and 2004 was detected in all Sudan states except Kassala and South Kordofan states where the situation remained as it is. Khartoum and West Kordofan maintained the highest degradation rate $(14.45 \%)$. The lowest degradation rate $(0.39 \%)$ was recorded for West Darfur state. Severe degradation rates were remarked for indicators associated with sex and age. A great degradation in sex ratio was taken place in most of the states of the country (in the range of $6.12 \%$. to $73.19 \%$ ). While the rate for ages between 6 and 24 years was in the rage of $1.88 \%$ to $25.43 \%$. However, such degradation may be an indication of the low level of the Crude Birth Rate (CBR). The analysis results for the Literacy Rate (LR) showed that high percentage of the population in the country is illiterate.

Rainfall distribution, agricultural activities and geological structures were found to have some impacts on the population distribution in Sudan. While the rainfall rate in most of the areas with lower growth rate was less than four inches, the rainfall rate in areas with highest growth rate was between 20 and 40 inches. Traditional agriculture was the main agricultural activity in density populated areas $(81.73 \%)$, while in poor areas only scattered vegetation was available (100\%). A great difference was remarked for the geological structures in density populated areas and poor areas. On the other hand underground water and soil types seam to have no or less impacts on population growth rate in the study area.

\section{References}

1. O'looney, J., Beyond Maps: GIS and Decision Making in local Governments. ESRI press, New York, 2000.

2. http://en.wikipedia.org/wiki/Image:World_population.PNG (access date 20/8/2007).

3. United Nation, World Urbanization Prospects, the 2003 Revision. UN Publication sales No. E.04.XIII.6, 2004.

4. Perston, Samuel, Heuveline, Patrick and Guillot, Michel, Demography, Blackwell, Oxford, 2002.

5. http://en.wikipedia.org/wiki/Demography (access date 20/8/2007).

6. http://en.wikipedia.org/wiki/Image:Sex_ratio_below_15_per_countrysmo oth.png (access date 20/8/2007). 


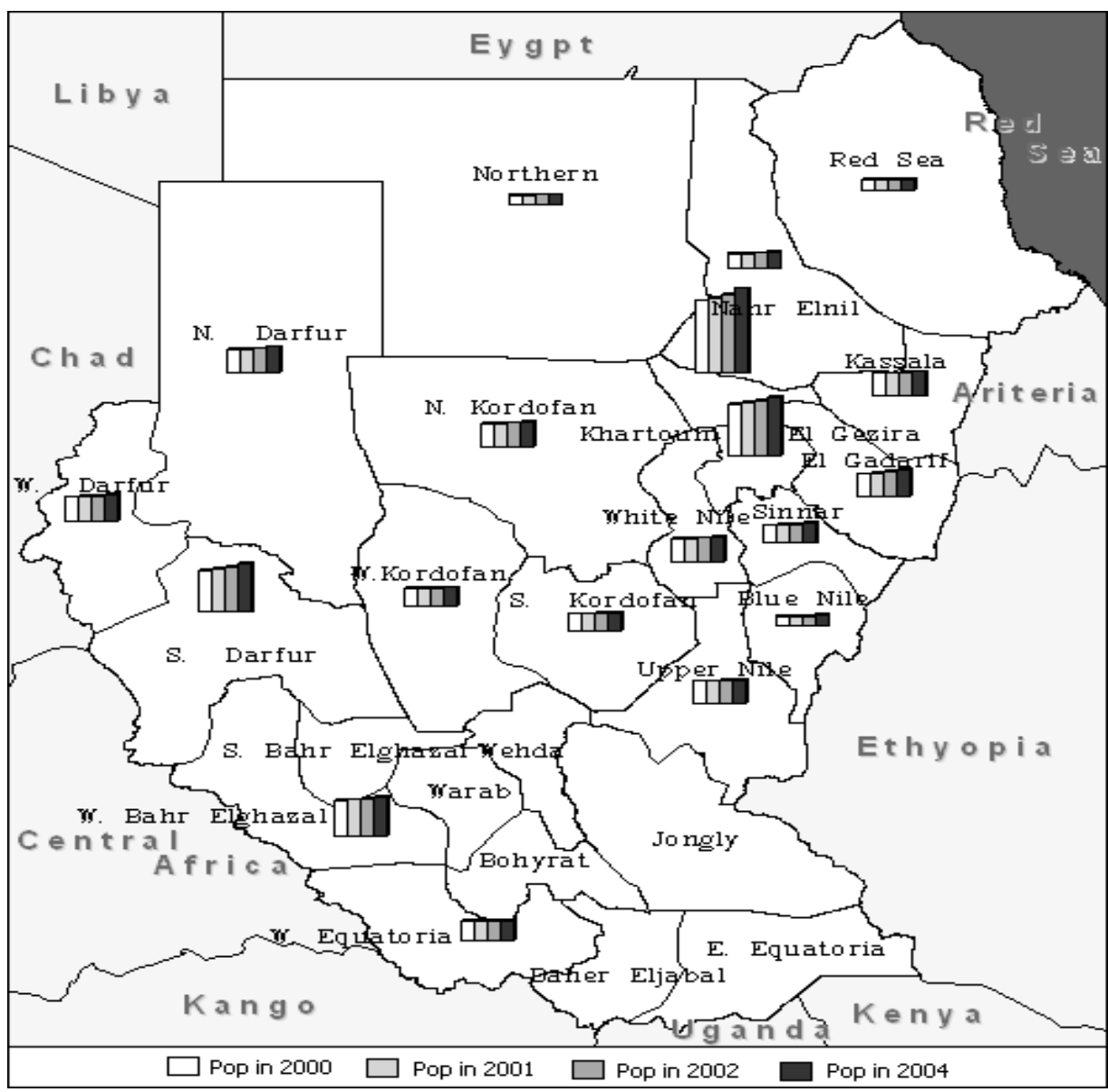

Figure 1: Population Growths at State Level during 2000 and 2004 

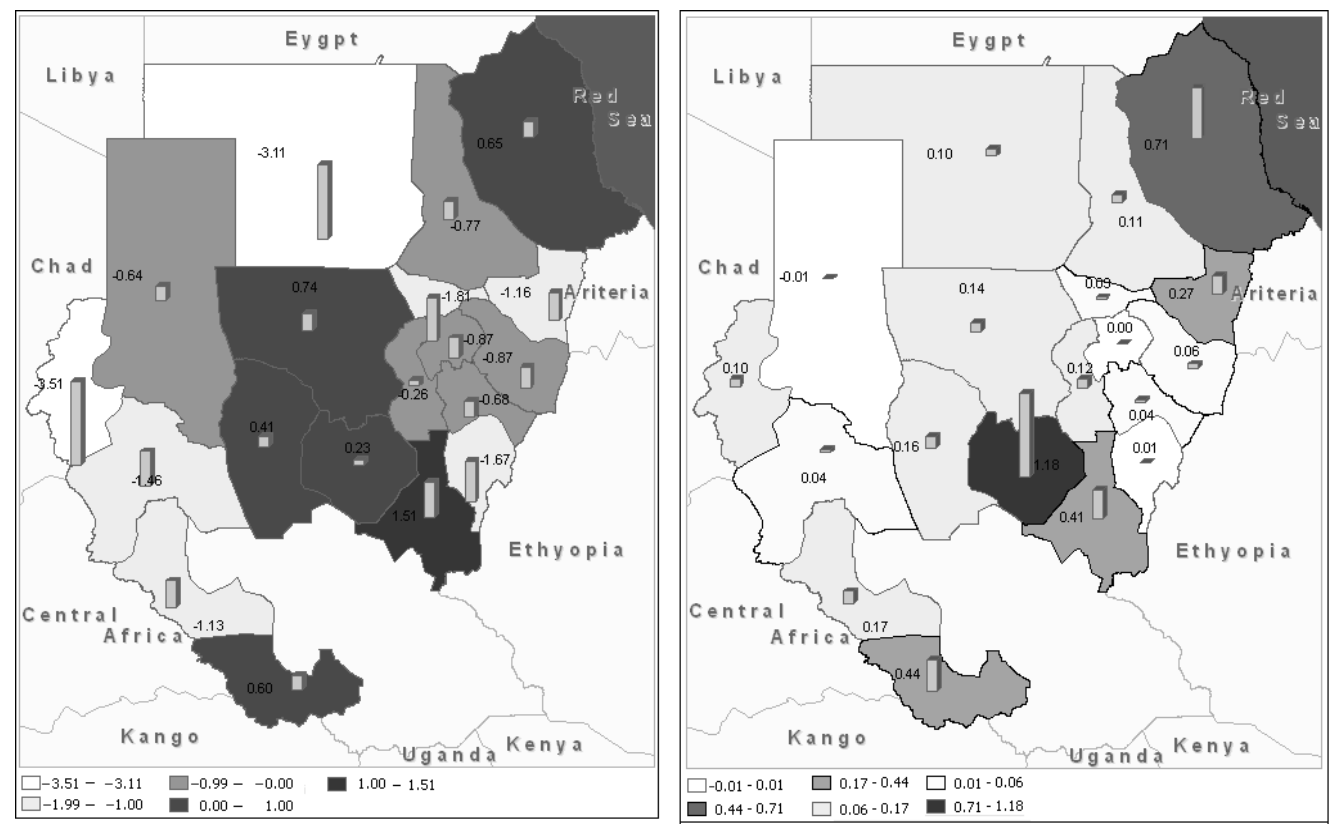

a) Growths for Ages between 6 and 24

b) Growths at Age 60 and over

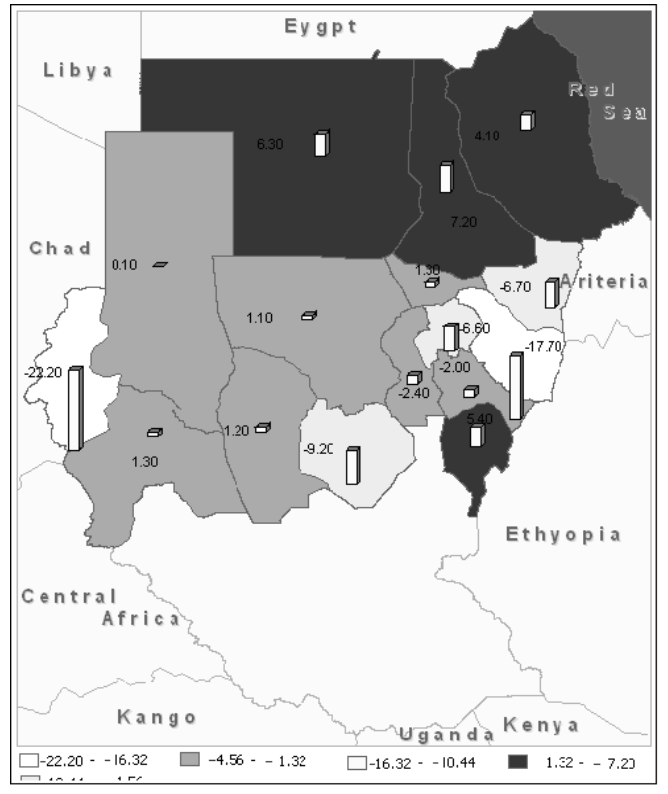

c) Literacy growths for both sex

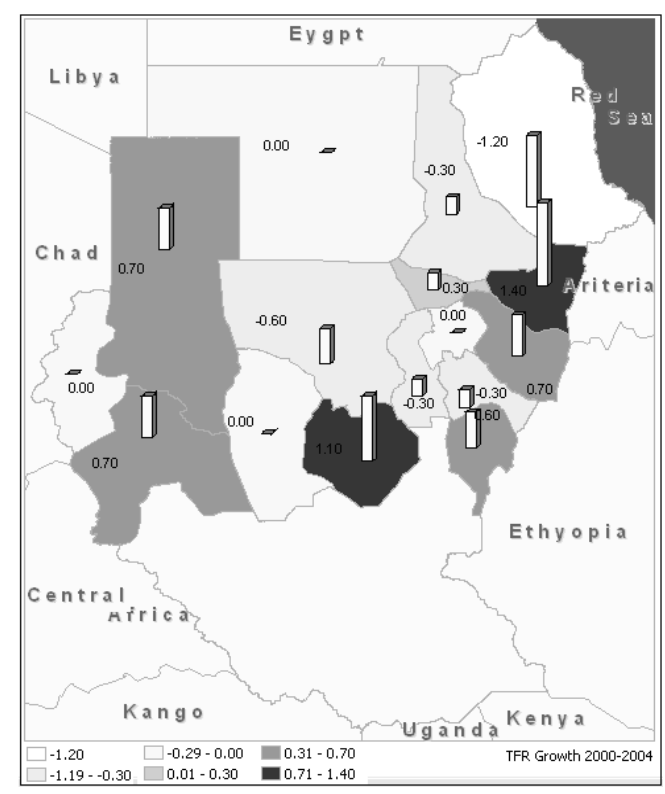

d) TFR Growths

Figure 2: Demographic Indicators at State Level during 2000 and 2004 


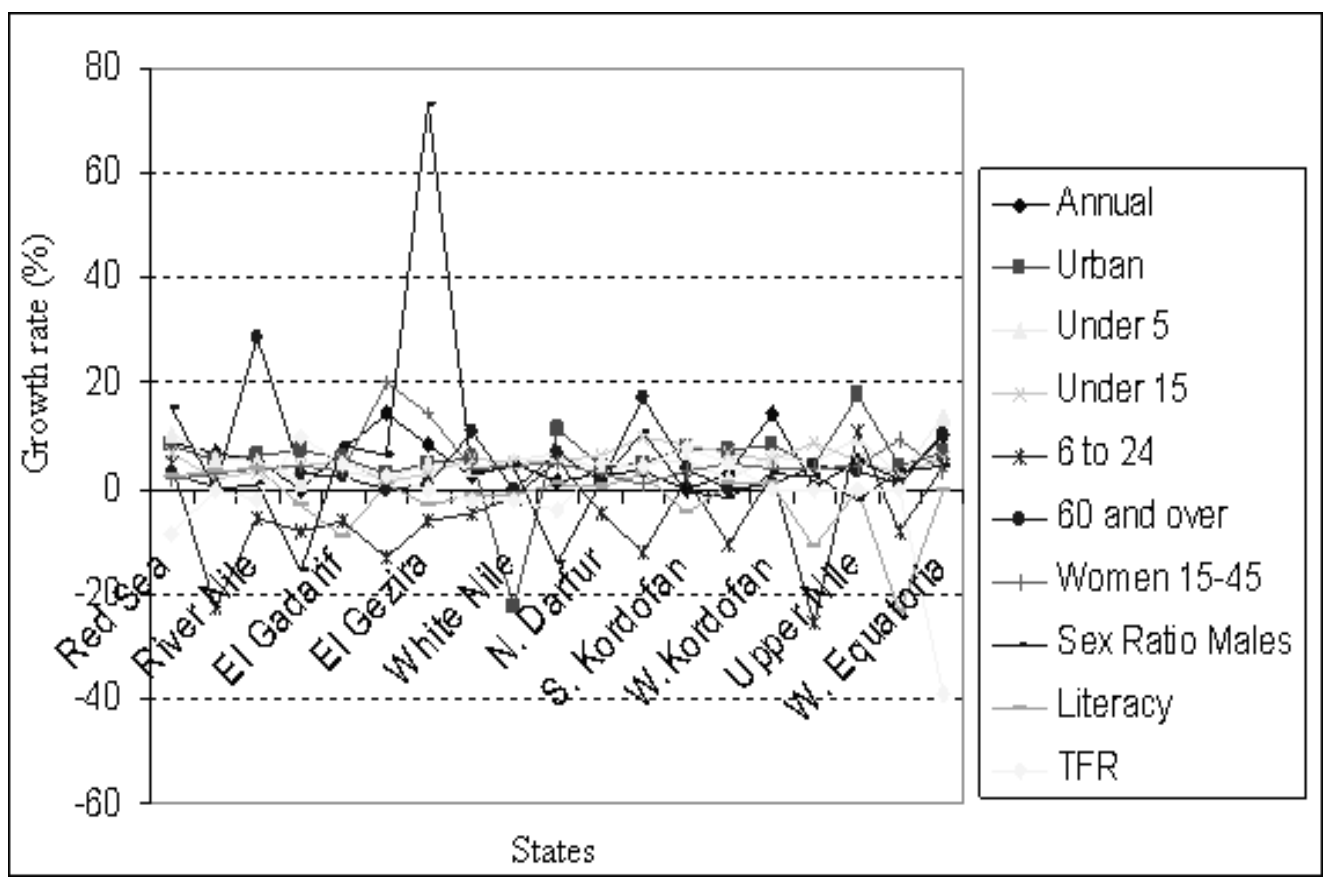

Figure 3 Graphical Analyses of the Demographic Indicators during 2000 and 2004 
Evaluation of the Demographic Situation....

Adil M. A. Elsinnari

Table 1: Population Growths at State Level during years 2000 and 2004

\begin{tabular}{|l|c|c|c|c|}
\hline \multirow{2}{*}{\multicolumn{1}{c|}{ STATE }} & \multicolumn{2}{c|}{ Estimated Population } & \multicolumn{2}{c|}{ Population Growth } \\
\cline { 2 - 5 } & Year 2000 & Year 2004 & Value & $\%$ \\
\hline El Gadarif & 1409000 & 1674000 & 265000 & 18.81 \\
\hline Khartoum & 4740000 & 5553000 & 813000 & 17.15 \\
\hline S. Darfur & 2760000 & 3171000 & 411000 & 14.89 \\
\hline N. Darfur & 1455000 & 1655000 & 200000 & 13.75 \\
\hline Blue Nile & 636000 & 716000 & 80000 & 12.58 \\
\hline El Gezira & 3374000 & 3797000 & 423000 & 12.54 \\
\hline Sinnar & 1173000 & 1301000 & 128000 & 10.91 \\
\hline White Nile & 1476000 & 1636000 & 160000 & 10.84 \\
\hline W. Darfur & 1577000 & 1734000 & 157000 & 9.96 \\
\hline W. Bahr Elghazal & 2321000 & 2550000 & 229000 & 9.87 \\
\hline River Nile & 900000 & 972000 & 72000 & 8.00 \\
\hline Northern & 582000 & 624000 & 42000 & 7.22 \\
\hline W. Kordofan & 1124000 & 1203000 & 79000 & 7.03 \\
\hline Kassala & 1525000 & 1625000 & 100000 & 6.56 \\
\hline N. Kordofan & 1483000 & 1578000 & 95000 & 6.41 \\
\hline S. Kordofan & 1111000 & 1174000 & 63000 & 5.67 \\
\hline W. Equatoria & 1261000 & 1310000 & 49000 & 3.89 \\
\hline Upper Nile & 1453000 & 1506000 & 53000 & 3.65 \\
\hline Red Sea & 721000 & 734000 & 13000 & 1.80 \\
\hline & Growth Average & & 180632 & 9.55 \\
\hline
\end{tabular}


Table 2: Growths Rate during 2000 and 2004

\begin{tabular}{|c|c|c|c|c|c|c|c|c|c|c|}
\hline \multirow[b]{2}{*}{ State } & \multicolumn{10}{|c|}{ Growth Rate \% during 2000 and 2004} \\
\hline & Annual & Urban & Under Age 5 & $\begin{array}{c}\text { Under } \\
\text { Age } \\
15\end{array}$ & $\begin{array}{c}\text { Age } 6 \text { to } \\
24\end{array}$ & $\begin{array}{c}\text { Age } \\
60 \\
\text { and } \\
\text { over }\end{array}$ & $\begin{array}{c}\text { Wom } \\
\text { en } \\
\text { Age } \\
15-45\end{array}$ & $\begin{array}{c}\text { Sex } \\
\text { Rati } \\
0\end{array}$ & $\begin{array}{c}\text { Liter } \\
\text { acy }\end{array}$ & TFR \\
\hline Red Sea & 8.59 & 8.26 & 10.26 & 6.95 & 4.71 & 2.70 & 1.68 & $\begin{array}{c}15.1 \\
3 \\
\end{array}$ & 2.10 & -8.5 \\
\hline Northern & 6.64 & 5.45 & 6.00 & 1.95 & -22.54 & 0.25 & 2.88 & 0.00 & 3.23 & 0.00 \\
\hline River Nile & 5.47 & 6.49 & 5.13 & 3.46 & -5.58 & 28.92 & 3.98 & 0.99 & 3.69 & -2.1 \\
\hline Kassala & 0.00 & 7.34 & 1.26 & 4.14 & -8.41 & 2.94 & 4.43 & $\begin{array}{c}- \\
15.8 \\
\end{array}$ & -3.43 & 9.93 \\
\hline El Gadarif & 7.03 & 5.66 & 3.47 & 5.03 & -6.30 & 2.45 & 3.50 & 8.21 & -9.07 & 4.96 \\
\hline Khartoum & 14.45 & 2.55 & 1.66 & 1.30 & -13.12 & 0.00 & 20.45 & 6.12 & 0.67 & 2.13 \\
\hline El Gezira & 8.20 & 4.53 & 4.58 & 2.96 & -6.30 & 0.74 & 14.30 & $\begin{array}{c}73.1 \\
9 \\
\end{array}$ & -3.38 & 0.00 \\
\hline Sinnar & 2.34 & 5.63 & 3.55 & 5.53 & -4.93 & 10.78 & 3.54 & 2.63 & -1.02 & -2.1 \\
\hline White Nile & 4.69 & -22.53 & 5.37 & 4.73 & -1.88 & -0.25 & 4.38 & 4.40 & -1.23 & -2.1 \\
\hline $\begin{array}{l}\text { N. } \\
\text { Kordofan }\end{array}$ & 1.17 & 11.19 & 6.87 & 5.19 & 5.36 & 6.62 & 4.78 & $\begin{array}{c}- \\
14.3 \\
\end{array}$ & 0.56 & -4.3 \\
\hline N. Darfur & 2.73 & 4.12 & 3.16 & 6.36 & -4.64 & 1.47 & 2.92 & 1.13 & 0.05 & 4.96 \\
\hline Blue Nile & 3.52 & 4.92 & 4.74 & 9.79 & -12.10 & 17.40 & 0.97 & $\begin{array}{c}10.5 \\
1\end{array}$ & 2.77 & 4.26 \\
\hline $\begin{array}{l}\text { S. } \\
\text { Kordofan }\end{array}$ & 0.00 & 7.61 & 5.13 & 8.12 & 1.67 & 3.92 & 3.05 & $\begin{array}{c}- \\
0.79 \\
\end{array}$ & -4.71 & 7.80 \\
\hline S. Darfur & 2.73 & 7.20 & 1.66 & 6.79 & -10.58 & 0.00 & 4.96 & $\begin{array}{c}- \\
1.63 \\
\end{array}$ & 0.67 & 4.96 \\
\hline $\begin{array}{l}\text { W.Kordof } \\
\text { an }\end{array}$ & 14.45 & 8.47 & 6.47 & 5.06 & 2.97 & 0.98 & 3.81 & 2.81 & 0.61 & 0.00 \\
\hline W. Darfur & 0.39 & 4.20 & 4.81 & 8.71 & -25.43 & 4.17 & 3.54 & 2.16 & $\begin{array}{c}- \\
11.3 \\
7 \\
\end{array}$ & 0.00 \\
\hline $\begin{array}{l}\text { Upper } \\
\text { Nile }\end{array}$ & 5.47 & 17.97 & 9.94 & 5.16 & 10.94 & 3.43 & 4.34 & $\begin{array}{c}- \\
2.07 \\
\end{array}$ & 0.00 & 0.00 \\
\hline $\begin{array}{l}\text { W. } \\
\text { Elghazal }\end{array}$ & 1.95 & 4.20 & 2.05 & 2.90 & -8.19 & 0.98 & 9.34 & 3.12 & -23.9 & 0.00 \\
\hline $\begin{array}{l}\text { W. } \\
\text { Equatoria }\end{array}$ & 10.16 & 6.75 & 13.89 & 5.87 & 4.35 & 10.05 & 3.14 & 4.09 & 0.00 & -39 \\
\hline
\end{tabular}


Table 3: Growths Rate during 2000 and 2004

\begin{tabular}{|c|c|c|c|c|c|c|c|c|c|c|}
\hline 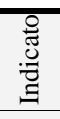 & $\begin{array}{c}\text { Highest } \\
\text { Growth } \\
\text { Rate } \\
\end{array}$ & $\begin{array}{c}\text { Lowest } \\
\text { Growth } \\
\text { Rate }\end{array}$ & & 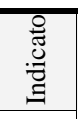 & $\begin{array}{c}\text { Highest } \\
\text { Growth } \\
\text { Rate }\end{array}$ & $\begin{array}{c}\text { Lowest } \\
\text { Growth } \\
\text { Rate }\end{array}$ & & & & \\
\hline & Class & $\begin{array}{l}\text { Area } \\
(\%)\end{array}$ & Class & $\begin{array}{c}\text { Area } \\
(\%)\end{array}$ & & & Class & $\begin{array}{c}\text { Area } \\
(\%)\end{array}$ & Class & $\begin{array}{c}\text { Area } \\
(\%)\end{array}$ \\
\hline \multirow{3}{*}{ 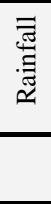 } & $\begin{array}{l}20 \text { to } 40 \\
\text { inch }\end{array}$ & 74.86 & $\begin{array}{l}\text { Les than } 4 \\
\text { inch }\end{array}$ & 79.65 & & \multirow{4}{*}{ 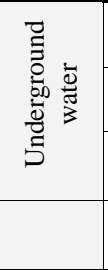 } & 1 & 99.18 & 1 & 99.63 \\
\hline & $\begin{array}{l}10 \text { to } 20 \\
\text { inch }\end{array}$ & 20.52 & \multirow{2}{*}{$\begin{array}{l}4 \text { to } 10 \\
\text { inch }\end{array}$} & \multirow{2}{*}{20.35} & & & 6 & 6.48 & 0 & 0.21 \\
\hline & $\begin{array}{l}4 \text { to } 10 \\
\text { inch }\end{array}$ & 4.62 & & & & & 0 & 0.17 & 8 & 0.09 \\
\hline \multirow{4}{*}{ 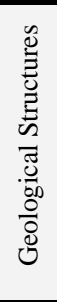 } & $\begin{array}{l}\text { Amhara } \\
\text { Plateau }\end{array}$ & 93.38 & $\begin{array}{l}\text { South Red } \\
\text { Sea Shield }\end{array}$ & 61.68 & & & & & 4 & 0.08 \\
\hline & \multirow{3}{*}{ Khartoum } & \multirow{3}{*}{6.45} & $\begin{array}{l}\text { North Red } \\
\text { Sea Shield }\end{array}$ & 37.77 & & \multirow{6}{*}{ 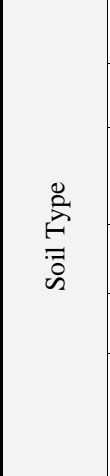 } & Basement & 50.95 & basement & 89.92 \\
\hline & & & $\begin{array}{l}\text { Red Sea } \\
\text { Basin }\end{array}$ & 0.34 & & & Gadarief & 20.54 & $\begin{array}{l}\text { Red sea } \\
\text { formation }\end{array}$ & 8.7 \\
\hline & & & $\begin{array}{l}\text { Upper } \\
\text { Egypt } \\
\text { Basin } \\
\end{array}$ & 0 & & & Basalt & 14.03 & $\begin{array}{l}\text { Baraka } \\
\text { (Toker) }\end{array}$ & 0.47 \\
\hline \multirow{3}{*}{ 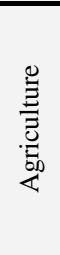 } & Traditional & 81.73 & \multirow{3}{*}{$\begin{array}{l}\text { Scattered } \\
\text { Vegetation }\end{array}$} & \multirow{3}{*}{100} & & & B. nile & 13.07 & $\begin{array}{l}\text { Alluvium } \\
\text { Basin }\end{array}$ & 0.41 \\
\hline & & & & & & & Attbara & 0.65 & Sallum & 0.2 \\
\hline & $\begin{array}{l}\text { Scattered } \\
\text { Vegetation }\end{array}$ & 18.27 & & & & & $\begin{array}{l}\text { Alluivium } \\
\text { Basin }\end{array}$ & 0.16 & $\begin{array}{l}\mathrm{N} \text { atbara } \\
\text { closed } \\
\text { sub_B }\end{array}$ & 0.08 \\
\hline
\end{tabular}

